\title{
PENGARUH PENGGUNAAN MEDIA SOSIAL, ELECTRONIC WORD OF MOUTH (EWOM) TERHADAP KEPUTUSAN PEMBELIAN KONSUMEN DAN DIMEDIASI OLEH KEPERCAYAAN
}

\author{
Cindy Arista Rusli ${ }^{1}$ dan M. Rachman Mulyandi'2) \\ 1)Universitas Matana, Tangerang \\ cindy.arista@matanauniversity.ac.id \\ 2)Universitas Matana, Tangerang \\ rachman.mulyandi@matanauniversity.ac.id
}

\begin{abstract}
Abstrak
Penelitian ini bertujuan untuk mengetahui pengaruh dari penggunaan media sosial, electronic word of mouth (e-wom), dan kepercayaan yang sebagai variabel mediasi terhadap keputusan pembelian konsumen. Pada perkembangan teknologi dan informasi penggunaan media sosial digunakan untuk menunjang gaya hidup dan dalam mencari informasi pengguna menggunakan media sosial yang mengkombinasikan antara ulasan, komentar, gambar, foto dan video. Penggunaan media sosial menciptakan keterikatan yang dapat menyebabkan terjadinya EWOM. Dengan semakin berkembangnya media sosial dan informasi yang lebih mudah didapatkan maka kepercayaan pengguna menjadi lebih penting. Pada beberapa penelitian yang telah dilakukan penggunaan media sosial, Ewom, dan kepercayaan dapat mempengaruhi keputusan pembelian konsumen. Metode yang digunakan dalam melakukan penelitian ini adalah metode tinjauan pustaka dari beberapa jurnal yang telah diteliti sebelumnya di beberapa negara. Dalam penelitian ini ditemukan hasil penggunaan media sosial secara langsung berpengaruh namun tidak signifikan, electronic word of mouth (EWOM) secara langsung berpengaruh signifikan terhadap keputusan pembelian, penggunaan media sosial yang dimediasi oleh kepercayaan memiliki pengaruh positif terhadap keputusan pembelian, dan electronic word of mouth yang dimediasi oleh kepercayaan memiliki dampak positif terhadap keputusan pembelian.
\end{abstract}

Kata Kunci: media sosial, electronic word of mouth, kepercayaan, keputusan pembelian

\begin{abstract}
This study aims to determine the effect of social media use, electronic word of mouth (e-wom), and trust as mediating variables on consumer purchasing decisions. In the development of technology and information the use of social media is used to support lifestyle and in seeking information users use social media that combines reviews, comments, images, photos and videos. The use of social media creates attachments that can lead to EWOM. With the development of social media and information that is easier to obtain, user trust is more important. In several studies that have been carried out using social media, Ewom, and trust can influence consumer purchasing decisions. The method used in conducting this research is a literature review method from several journals that have been previously studied in several countries. In this study it was found that the results of social media use were directly influential but not significant, electronic word of mouth (EWOM) directly had a significant effect on purchasing decisions, the use of social media mediated by trust had a positive influence on purchasing decisions, and electronic word of mouth mediated by trust has a positive impact on purchasing decisions.
\end{abstract}

Keywords: social media, electronic word of mouth, trust, purchase decision

\section{PENDAHULUAN}

\section{Latar Belakang}

Perkembangan pengguna internet di Indonesia mengalami peningkatan di setiap tahunnya. Pada tahun 2013 pengguna internet telah mencapai 82 juta jiwa serta pada tahun 2017 telah mencapai 143,26 juta jiwa. Data tersebut dapat digunakan untuk menunjukan bahwa saat ini perkembangan internet yang semakin berkembang dan tingkat kesadaran masyarakat terhadap internet telah meningkat. Berdasarkan dari 
data yang diluncurkan oleh APJII 2017 internet diakses melalui perangkat komputer atau laptop pribadi sebanyak $4,49 \%$, sedangkan sebanyak $44,16 \%$ menggunakan telepon pintar atau tablet, dan yang mengakses internet menggunakan kedua perangkat tersebut yaitu sebesar 39,28\%, lalu pengguna internet $12,07 \%$ menggunakan perangkat lainnya (APJII, 2017).

Dengan banyaknya penggunaan smartphone pada saat ini diseimbangi juga dengan peningkatan pertumbuhan jumlah pengguna smartphone dalam lima tahun terakhir dari tahun 2013 hingga tahun 2017 mengalami peningkatan. Pada tahun 2013 pengguna smartphone sebanyak 27,4 juta, dan pada tahun 2017 mencapai 86,6 juta, pengguna smartphone dalam lima terakhir mengalami peningkatatan sebesar $216,05 \%$. Dengan adanya peningkatan jumlah pengguna smartphone maka diiringi dengan jumlah aplikasi untuk smartphone juga mengalami peningkatan (Dailysocial, 2018). Aplikasi mobile yang sudah menjadi sebuah kebutuhan dari pengguna smartphone, maka pada lima tahun terakhir dari tahun 2013 hingga tahun 2017 mengalami peningkatan, pada tahun 2013 aplikasi mobile di google play store sebanyak satu juta aplikasi, dan pada tahun 2017 jumlah aplikasi di google play store telah mencapai 3,5 juta (Statista, 2018).

Pada aplikasi yang terdapat pada google play store mempunyai daerah asal pengembangan yang pertama adalah aplikasi yang dikembangkan oleh pengembang lokal dan aplikasi yang dikembangkan oleh pengembang asing (Dailysocial, 2018).

Berdasarkan survey yang telah dilakukan bahwa responden mendapatkan informasiinformasi mengenai aplikasi lokal dari media sosial yang merupakan sumber paling tinggi dalam memberikan informasi sebesar $48,55 \%$ dan yang kedua mendapatkan informasi dari rekomendasi teman sebanyak $21,44 \%$ (Dailysocial, 2018). Hal tersebut juga didukung oleh data dari APJII yang menyatakan bahwa perilaku pengguna internet di Indonesia yang memiliki kecenderungan dalam menggunakan layanan chatting sebesar $89,35 \%$, dan yang sering digunakan adalah media sosial sebanyak $87,13 \%$.
Berdasarkan dari APJII pada 2017 penggunaan internet dalam bidang gaya hidup didominasi oleh penggunaan media sosial (APJII, 2017). Menurut data wearesocial pada Januari 2018 pengguna aktif media sosial di Indonesia sebesar 130 juta. Pada saat ini media sosial dapat mempengaruhi perilaku konsumen (Wearesocial, 2018).

Menurut Jay M. Bernhardt 2012 yang menyatakan bahwa media sosial saat ini dapat digunakan sebagai media informasi yang lebih dapat dipercaya. Pada media sosial terdapat berbagai macam informasi yang ada pada seluruh dunia dan konsumen dapat melakukan perbandingan serta dapat saling berinteraksi. Media sosial memiliki fitur definisi yang tingkat keterlibatan pengguna menjadikan pengguna sebagai pusat dari pertukaran informasi, pembuat konten, membagikan informasi, dan sebagai kolaborator langsung (Jay M. Bernhardt, 2012). Pada media sosial tingkat keterlibatan pengguna memiliki tingkat keterlibatan yang berbeda-beda (Shantanu Prasad, 2017).

Keterlibatan pada media sosial meliputi segala tindakan yang menimbulkan interaksi terhadap konten yang tersedia di media sosial seperti like, membagikan kiriman dan komentar yang dilakukan oleh pengguna (Morse, 2016).

Tindakan pengguna yang menyebabkan terjadinya keterlibatan dari pengguna dapat membentuk adanya EWOM pada media sosial. Ewom adalah bentuk dari Word of Mouth (WOM) yang medianya melalui internet. Word of mouth mempunyai arti yaitu komunikasi yang dilakukan secara langsung antar konsumen mengenai sebuah produk atau merek. Dengan adanya perkembangan teknologi informasi dan komunikasi yang membentuk WOM dapat berkembang menjadi EWOM (Electronic Word of Mouth) (Shantanu Prasad, 2017).

Berdasarkan jurnal, electronic word of mouth atau EWOM adalah sebuah pernyataan berasal dari calon pelanggan, pelanggan sesungguhnya atau mantan pelanggan dapat bersifat positif atau negatif mengenai sebuah produk atau perusahaan yang disediakan bagi banyak orang dan lembaga melalui internet. Dalam komunikasi EWOM hal yang paling terpenting adalah ulasan dari konsumen (Thorsten HennigThurau, 2004). Sebesar $61 \%$ konsumen 
sebelum membuat sebuah keputusan pelanggan akan membaca ulasan terlebih dahulu. Maka dari itu ulasan lebih dapat dipercaya oleh pelanggan daripada komunikasi dari perusahaan seperti iklan (Oleksandra Pasternak, 2017). EWOM memiliki pengaruh positif dalam peran penting pada niat pembelian hal tersebut didukung oleh beberapa penelitian dan jurnal.

EWOM adalah media yang dapat dimanfaatkan oleh pelanggan untuk mendapatkan informasi mengenai layanan atau produk, serta pelanggan dapat menggunakan informasi dari EWOM untuk mengurangi ketidakpastian atau resiko. Dalam mengurangi ketidakpastian maka kepercayaan dikembangkan (Shantanu Prasad, 2017). Kepercayaan merupakan motivasi individu dalam bertindak atas atau mengikuti saran, informasi atau pengetahuan yang diberikan oleh individu lainnya. Peran penting dari kepercayaan adalah dalam merangsang orang untuk saling bertukar penilaian, informasi atau pandangan mengenai sebuah merek atau produk (Milad Farzin, 2018).

Dengan adanya fenomena penggunaan media sosial dan EWOM yang mempunyai pengaruh terhadap keputusan pembelian. Hal tersebut didukung oleh hasil dari penelitian sebelumnya, bahwa penggunaan media sosial dan EWOM berpengaruh terhadap keputusan pembelian (Shantanu Prasad, 2017).

\section{Deskripsi Permasalahan}

Dengan adanya perkembangan teknologi dan informasi, maka penulisan ini bertujuan untuk mengetahui pengaruh dari penggunaan media sosial, electronic word of mouth (e-wom), dan kepercayaan yang sebagai variabel mediasi terhadap keputusan pembelian konsumen.

\section{TINJAUAN PUSTAKA}

\section{Media Sosial}

Menurut Advocate/Burson-Marsteller 2012, dalam Tsimonis (2014) Media sosial merupakan suasana yang relatif baru dan berkembang pesat di mana akademisi dan perusahaan belum memiliki pengetahuan yang kuat.
Media sosial menurut Kaplan dan Haenlein (2010) dalam Ismail (2017) mendefinisikan sebagai "sekelompok aplikasi berbasis internet yang membangun fondasi ideologis dan teknis Web 2.0, dan yang memungkinkan penciptaan dan pertukaran konten yang dibuat pengguna".

Menurut Cook (2008) dalam McCann (2015) Media sosial mencerminkan cara-cara dari masing-masing konten (terutama pada berita dan opini) media sosia merupakan salah satu indikator dari internet bahwa internet bersifat terbuka dan saat ini orang tidak hanya mengonsumsi informasi dan menyampaikannya kepada orang lain, namun juga dapat menciptakan dan berbagi konten dengan orang lain. Menurut (Safko, 2010; Kaplan dan Haenlein, 2010; Cook, 2008) Media sosial telah menciptakan cara baru yang revolusioner agar dapat berinteraksi, berpartisipasi, bekerja sama dan berkolaborasi dan melibatkan pengguna yang menghasilkan konten dan menghubungkan dengan orang-orang melalui pendekatan komunikasi dua arah.

Menurut penjelasan diatas maka penulis berpendapat bahwa media sosial sebuah aplikasi berbasis internet yang dapat digunakan untuk saling interaksi, berkolaborasi, dan yang dapat menjalin komunikasi dua arah, dalam media sosial pengguna dapat membuat konten dan membagikannya kepada orang lain.

\section{Electronic Word of Mouth (EWOM)}

Electronic Word of Mouth merupakan sebuah pernyataan dari calon pelanggan, pelanggan yang sesungguhnya atau mantan pelanggan yang bersifat positif atau negatif mengenai sebuah produk atau perusahaan yang tersedia bagi banyak orang dan lembaga melalui internet. Komunikasi EWOM telah menjadi sebuah platform penting bagi pendapat konsumen. Produk ulasan konsumen yang di posting pada internet merupakan salah satu bentuk yang paling penting dari komunikasi eWOM (Milad Farzin, 2018).

\section{Kepercayaan}

Kepercayaan sangat berkaitan dengan pembelian konsumen secara online yang positif mempengaruhi niat pembelian. Untuk mempertahankan hubungan dengan 
konsumen, maka menciptakan kepercayaan online adalah salah satu faktor yang penting karena hal tersebut adalah salah satu alasan untuk situs web dapat sukses. Berdasarkan hasil penelitian, kepercayaan secara langsung mempengaruhi niat pembelian dalam berbagai budaya (Rawin Vongurai, 2018).

Kepercayaan merupakan faktor yang memengaruhi keputusan pembelian. Morgan dan Hunt menjelaskan bahwa kepercayaan muncul sebagai akibat dari reabilitas dan integritas pasangan, yang ditunjukkan melalui berbagai sikap seperti konsistensi, kompetensi, keadilan, tanggung jawab, dan kepedulian. Kim, Ferrin dan Rao menerangkan bahwa kepercayaan memainkan peran penting dalam sistem ecommerce, kepercayaan adalah pemikiran pertama seorang konsumen sebelum melakukan transaksi online. Jika pelanggan tidak mempercayai e-commerce, maka pelanggan tidak akan membeli produk atau layanan. Kepercayaan berpengaruh signifikan terhadap keputusan pembelian karena banyak pelanggan yang sudah memercayai produk seperti Traveloka Apps (Handi Handi, 2018).

\section{Keputusan Pembelian}

Dalam tahap Keputusan Pembelian, konsumen mempunyai minat dan perhatian yang adalah konsep dari pola pikir konsumen dengan berbicara mengenai antisipasi dalam keputusan pembelian. Karena ada banyak alternatif dan pilihan merek yang tersedia di pasar, maka konsumen mempertimbangkan pilihan yang paling tepat bagi konsumen tersebut dan menghasilkan pilihan yang tepat selama proses pengambilan keputusan (Rawin Vongurai, 2018).

Keputusan pembelian melibatkan urutan pilihan yang dibentuk oleh konsumen sebelum melakukan pembelian yang dimulai begitu konsumen telah memiliki keinginan untuk memenuhi suatu kebutuhan. Konsumen harus mencapai sebuah keputusan berhubungan dengan tempat pembelian, merek yang diinginkan, model, jumlah pembelian, waktu untuk membeli, jumlah uang yang akan dibelanjakan dan metode pembayaran. Keputusan tersebut dapat dipengaruhi oleh pemasar dengan memberikan informasi tentang produk atau layanan pemasar yang dapat menginformasikan proses penilaian konsumen. Konsumen biasanya mencari informasi yang relevan mengenai kebutuhan berkaitan dengan konsumsi tertentu dari pengalaman masa lalu mereka sebelum mencari sumber informasi eksternal. Pengalaman pembelian masa lalu dianggap sebagai sumber informasi internal yang diandalkan konsumen sebelum membuat keputusan. Beberapa keputusan yang dibuat oleh konsumen kemungkinan besar akan dibentuk dengan mengintegrasikan pengalaman pembelian masa lalu serta program pemasaran dan sumber informasi non-komersial. Konsumen berusaha meminimalkan risiko dalam keputusan pembeliannya (Hanaysha, 2018).

Dalam memahami keputusan pembelian konsumen, manajer pemasaran harus memahami proses konsumsi mereka dan manfaat dari produk dan layanan organisasi dalam persepsi konsumen. Ketika konsumen berniat untuk sebuah membeli produk tertentu, maka konsumen melewati banyak tahapan yang akan mempengaruhi proses keputusan pembelian dan perilaku pasca pembelian konsumen. Tahapan pertama merupakan pengenalan masalah di mana konsumen berniat untuk memenuhi kebutuhan dan keinginan mereka. Peran pemasar dalam tahapan ini muncul saat menggunakan iklan, penjualan pribadi dan kemasan untuk membangkitkan pengakuan kebutuhan atau keinginan yang diinginkan. Pada tahapan kedua, konsumen mulai mencari informasi dari sumber internal (biasanya dari pengalaman masa lalu) tentang produk atau sumber luar, misalnya, teman, keluarga, kerabat, tetangga, laporan tahunan, publikasi, tenaga penjualan, media sosial atau label kemasan.Terakhir, konsumen mengevaluasi alternatif dan memilih dari merek yang paling sesuai dengan mereka dan memenuhi kebutuhan konsumen (Hanaysha, 2018).

\section{PEMBAHASAN}

Menurut Kotler dan Keller dalam (Handi Handi, 2018), pada tahap evaluasi, konsumen akan memilih satu hal yang disukai di antara beberapa merek dan juga akan menciptakan niat untuk membelinya. Ini berarti bahwa orang akan memutuskan apakah suatu produk atau layanan yang 
akan dibeli sudah ada di antara opsi alternatif, memungkinkan evaluasi dan pilihan terbaik pada akhirnya. Schiffman dan Kanuk dalam (Handi Handi, 2018) keputusan pembelian adalah pilihan dari dua alternatif, yang artinya adalah ketika konsumen membuat keputusan pembelian, tindakan tersebut sudah untuk memilih salah satu dari beberapa opsi. Keputusan pembelian melibatkan bagaimana proses pengambilan keputusan dilakukan. Studi sebelumnya menunjukkan bahwa salah satu faktor yang mempengaruhi keputusan pembelian adalah kata elektronik dari mulut ke mulut. Jalilvand dan Samiei dalam (Handi Handi, 2018) kata elektronik dari mulut ke mulut adalah ruang online yang penting bagi pelanggan untuk memberikan pendapatnya dan dianggap lebih efektif daripada kata dari mulut ke mulut karena cakupan dan aksesibilitasnya lebih luas. Sebuah studi yang dilakukan oleh Themba dan Mualala dalam (Handi Handi, 2018) kata elektronik dari mulut ke mulut berpengaruh secara positif dan signifikan terhadap keputusan pembelian. Ini berarti pengalaman yang diungkapkan melalui kata elektronik dari mulut ke mulut akan memengaruhi keputusan pembelian. Chang, Lee dan Huang juga menemukan bahwa kata elektronik dari mulut ke mulut berpengaruh secara positif dan signifikan terhadap keputusan pembelian. Almana dan Mirza memperkuat temuan bahwa kata elektronik dari mulut ke mulut berpengaruh positif dan signifikan terhadap keputusan pembelian. Hal ini disebabkan banyak konsumen memperoleh informasi tentang produk online, terutama komentar dan ulasan oleh konsumen lain.

Pada penelitian yang diteliti oleh Shantanu Prasad, Ishwar C. Gupta, Navindra K. Totala, (2017), penelitian yang dilakukan di Pune, India. dan memiliki tujuan yang memberikan nilai dalam pandangan terhadap media sosial, electronic word of mouth (EWOM), kepercayaan dan keterlibatan keputusan pembelian.

Hipotesis dalam penelitian ini yaitu:

$\mathrm{H} 1$. Penggunaan media sosial memiliki dampak langsung yang signifikan terhadap keterlibatan keputusan pembelian.

H2. EWOM memiliki dampak langsung yang signifikan terhadap keterlibatan keputusan pembelian.
H3. Dampak penggunaan media sosial pada keterlibatan keputusan pembelian dimediasi oleh kepercayaan.

H4. Dampak EWOM pada keterlibatan keputusan pembelian dimediasi oleh kepercayaan.

Hasil dari penelitian ini adalah sebagai berikut.

1. Penggunaan media sosial memiliki dampak positif yang signifikan secara langsung pada keterlibatan pembeliankeputusan.

2. Ewom memiliki pengaruh positif yang signifikan terhadap keputusan pembelian konsumen.

3. 3.Penggunaan media sosial mempengaruhi (secara signifikan) kepercayaan pelanggan secara positif dan kepercayaan memiliki dampak positif yang signifikan dari keterlibatan keputusan pembelian.

4. EWOM mempengaruhi (secara signifikan) kepercayaan pelanggan secara positif, serta kepercayaan juga memediasi sebagian pengaruh EWOM pada keterlibatan keputusan pembelian.

Pada penelitian yang diteliti oleh Rawin Vongurai, Dinesh Elango, Kitti Phothikitti, Usakorn Dhanasomboo, pada tahun 2018 dilakukan di Bangkok, Thailand (Rawin Vongurai, 2018).

Hipotesis dalam penelitian ini yaitu :

H1a: Penggunaan Media Sosial secara signifikan memengaruhi Kepercayaan dalam menggunakan Layanan Perjalanan.

$\mathrm{H} 1 \mathrm{~b}$ : Electronic Word of Mouth secara signifikan memengaruhi Kepercayaan dalam menggunakan Layanan Perjalanan.

H2a: Penggunaan Media Sosial secara signifikan mempengaruhi keterlibatan Pembelian-Keputusan dalam menggunakan Layanan Perjalanan.

$\mathrm{H} 2 \mathrm{~b}$ : Kepercayaan secara signifikan mempengaruhi keterlibatan Purchase Decision dalam menggunakan Layanan Perjalanan.

H2c: Electronic Word of Mouth secara signifikan mempengaruhi keterlibatan Pembelian-Keputusan dalam menggunakan Layanan Perjalanan.

Pada penelitian ini didapatkan hasil sebagai berikut :

1. Penggunaan media sosial memiliki hubungan yang tidak terlalu signifikan 
$\begin{array}{lrr}\text { (sedang) terhadap } & \text { keterlibatan } \\ \text { keputusan } & \text { pembelian } & \text { dalam } \\ \text { menggunakan layanan perjalanan orang } \\ \text { di Bangkok }\end{array}$

2. Electronic word of mouth (EWOM) memiliki hubungan moderat dengan keterlibatan keputusan pembelian dalam menggunakan layanan perjalanan orang di Bangkok

3. Kepercayaan memiliki hubungan moderat dengan keterlibatan keputusan pembelian perjalanan untuk orang di Bangkok.

Dalam penelitian ini, Regresi Linier Berganda (MLR) sudah diterapkan didalam analisis inferensial untuk menguji $\mathrm{H} 1 \mathrm{a}$ dan $\mathrm{H} 1 \mathrm{~b}$, Penggunaan Media Sosial (SC) dan Electronic Word of Mouth (E-WOM) secara signifikan mempengaruhi Kepercayaan (T) dalam menggunakan Layanan Perjalanan untuk orang Bangkok. Analisis Inferensial menguji $\mathrm{H} 2 \mathrm{a}, \mathrm{H} 2 \mathrm{~b}$, dan $\mathrm{H} 2 \mathrm{c}$ apakah Penggunaan Media Sosial (SC), Electronic Word of Mouth (E-WOM) dan Kepercayaan (T) secara signifikan mempengaruhi keterlibatan keputusan pembelian (PD) dalam menggunakan Layanan Perjalanan untuk orang Bangkok.

Pada penelitian pada tahun 2017 dan diteliti oleh Eleftherios Varkaris dan Barbara Neuhofer. menyatakan ketika konsumen menggunakan media sosial dan menggunakan berbagai jenis saluran web 2.0 untuk melakuan pencarian hotel yang komprehensif dengan TripAdvisior menjadi saluran yang paling signifikan, diikuti oleh media sosial facebook, instagram, youtube dan twitter. Platform sosial yang berbeda untuk spesifik yang tujuannya berbeda. Pada penelitian ini memberitahukan bahwa media sosial merupakan saluran utama dalam konsumen mencari sebuah informasi, sementara itu dapat dilengkapi dengan menggunakan mesin pencari, kunjungan ke situs web resmi hotel untuk mencari informasi dan membuat keputusan sebelum memesan hotel. Alasan yang mendasari penggunaan media sosial terutama terkait dengan kemampuan untuk menawarkan sebuah informasi yang diperlukan mengenai berbagai hotel dan menjawab pertanyaan dari individu yang dapat melalui kombinasi antara ulasan, komentar, peringkat, gambar dan video untuk memperkuat proses pengambilan keputusan secara keseluruhan. Dalam penelitian ini terdapat berbagai alasan yang membedakan penggunaan media sosisal terkait dengan kelebihan dan kekurangan proses peralihan antara web 1.0 dan 2.0. Tingkat kepercayaan yang berkaitan dengan sumber konten dan jenis konten dan menunjukkan pengaruh berbagai tingkat konten pada akhir pengambilan keputusan.

Berdasarkan serangkaian informasi penelitian ini, yang memengaruhi proses pemilihan hotel, tahap evaluasi disimpulkan dengan keputusan akhir konsumen, memutuskan untuk melanjutkan dengan pilihan hotel tertentu menuju Tahap Pemesanan (putaran umpan balik - tahap berikutnya), atau menolak pilihan hotel tertentu dan memulai kembali informasi dan tahap evaluasi (umpan balik - pengulangan tahap).

Pada penelitian yang dilakukan pada tahun 2016 yang diteliti oleh Keles Dikna Maria, Paulus Kindangen, Farlane S. Rumokoy dilakukan di Manado, Indonesia (Keles Dikna Maria, 2016).

Penelitian ini mempunyai hipotesis sebagai berikut :

H1: Pengalaman E-WOM, persepsi kredibilitas, dan kerentanan pelanggan terhadap pengaruh interpersonal (CSII) secara simultan mempengaruhi keputusan pembelian konsumen pada Lazada.

$\mathrm{H} 2$ : Pengalaman E-WOM memengaruhi sebagian keputusan pembelian konsumen tentang Lazada.

H3: Persepsi kredibilitas mempengaruhi sebagian keputusan pembelian konsumen tentang Lazada.

H4: Kerentanan pelanggan terhadap pengaruh interpersonal memengaruhi sebagian keputusan pembelian konsumen Lazada.

Dalam penelitian ini ditemukan hasil-hasil yaitu :

1. Semua variabel independen yang mengalami E-WOM, persepsi kredibilitas, dan kerentanan pelanggan terhadap pengaruh interpersonal secara simultan memengaruhi keputusan pembelian konsumen atas produk Lazada.

2. Pengalaman E-WOM memiliki pengaruh positif dan signifikan secara parsial terhadap keputusan pembelian 
konsumen atas produk Lazada sebagai variabel dependen.

3. Kredibilitas yang dirasakan memiliki pengaruh negatif dan tidak signifikan sebagian terhadap keputusan pembelian produk Lazada oleh konsumen.

4. Kerentanan pelanggan terhadap pengaruh interpersonal berpengaruh positif dan tidak signifikan secara parsial terhadap keputusan pembelian konsumen atas produk Lazada.

Pada Jurnal yang berjudul "An examination of the factors affecting consumer's purchase decision in the Malaysian retail market' yang diteliti oleh Jalal Rajeh Hanaysha, (2018) di Malaysia.

Dalam penelitian ini memiliki hipotesis sebagai berikut :

$\mathrm{H} 1$. Tanggung jawab sosial perusahaan memiliki efek positif pada keputusan pembelian.

H2. Pemasaran media sosial memiliki efek positif pada keputusan pembelian.

H3. Lingkungan toko memiliki efek positif pada keputusan pembelian

H4. Promosi penjualan memiliki efek positif pada keputusan pembelian

H5. Nilai yang dirasakan memiliki efek positif pada keputusan pembelian

Penelitian ini memiliki hasil sebagai berikut.

1. Tanggung jawab sosial perusahaan memiliki efek positif yang signifikan terhadap keputusan pembelian

2. Pemasaran media sosial memiliki pengaruh yang tidak signifikan terhadap keputusan pembelian

3. Lingkungan toko memiliki efek positif yang signifikan terhadap keputusan pembelian

4. Promosi penjualan memiliki pengaruh negatif yang signifikan terhadap keputusan pembelian;

5. Nilai yang dirasakan memiliki efek positif yang signifikan pada keputusan pembelian.

Pada jurnal yang ditelitih oleh Handi Handi, Tonny Hendratono, Edi Purwanto, John J.O.I. Ihalauw, tahun 2018 yang berjudul "The Effect of E-WOM and Perceived Value on the Purchase Decision of Foods by Using the Go-Food Application as Mediated by Trust"
Dalam jurnal ini terdapat lima hipotesis yaitu :

$\mathrm{H} 1$ : Electronic Word of Mouth (EWOM) berpengaruh positif pada keputusan pembelian.

H2: Nilai yang dirasakan mempengaruhi secara positif pada keputusan pembelian.

H3: Kepercayaan berdampak positif pada keputusan pembelian.

H4: Electronic Word of Mouth (EWOM) berpengaruh positif pada kepercayaan.

H5: Nilai yang dipersepsikan mempengaruhi secara positif pada kepercayaan.

Hasil dari penelitian ini adalah ;

1. Elektronik dari mulut ke mulut berpengaruh secara signifikan dan positif terhadap kepercayaan;

2. Nilai yang dirasakan mempengaruhi secara signifikan dan positif pada kepercayaan;

3. Electronic Word of Mouth (EWOM) berpengaruh secara signifikan dan positif terhadap keputusan pembelian;

4. Nilai yang dirasakan mempengaruhi secara signifikan dan positif pada keputusan pembelian;

5. Kepercayaan berpengaruh secara signifikan dan positif terhadap keputusan pembelian.

Dalam penelitian ini terdapat empat hipotesis:

$\mathrm{H} 1$ : Penggunaan media sosial berpengaruh positif secara langsung terhadap keputusan pembelian

$\mathrm{H} 2$ : Electronic Word of Mouth (EWOM) berpengaruh positif secara langsung terhadap keputusan pembelian

H3 : Penggunaan media sosial yang dimediasi oleh kepercayaan berpengaruh positif terhadap keputusan pembelian

$\mathrm{H} 4$ : Electronic Word of Mouth yang dimediasi oleh kepercayaan berpengaruh positif terhadap keputusan pembelian

Media sosial digunakan untuk mencari informasi mengenai produk atau jasa yang ada di pasar, dan konsumen menggunakan kombinasi antara ulasan, foto, video, komentar, dan peringkat dalam memperkuat konsumen dalam memperkuat keputusan pembelian. Dari beberapa jurnal yang dijadikan tinjauan pustaka dari penelitian ini maka hasil yang didapat adalah penggunaan media sosial secara langsung berpengaruh 
namun tidak signifikan, electronic word of mouth (EWOM) secara langsung berpengaruh signifikan terhadap keputusan pembelian, penggunaan media sosial yang dimediasi oleh kepercayaan memiliki pengaruh positif terhadap keputusan pembelian, dan electronic word of mouth yang dimediasi oleh kepercayaan memiliki dampak positif terhadap keputusan pembelian.

\section{KESIMPULAN}

Dari penelitian ini maka hasil yang didapat adalah penggunaan media sosial secara langsung berpengaruh namun tidak signifikan, electronic word of mouth (EWOM) secara langsung berpengaruh signifikan terhadap keputusan pembelian, penggunaan media sosial yang dimediasi oleh kepercayaan memiliki pengaruh positif terhadap keputusan pembelian, dan electronic word of mouth yang dimediasi oleh kepercayaan memiliki dampak positif terhadap keputusan pembelian. Sehingga saran bagi penelitian selanjutnya untuk penelitian dengan menggunakan media sosial dan electronic word of mouth sebagai variabel independen sebaiknya menggunakan variabel mediasi untuk menguji pengaruh terhadap variabel dependen sehingga tidak langsung menggunakan hubungan langsung terhadap variabel dependen karena dari hasil studi pustaka yang telah dilakukan peneliti ketika peneliti yang menggunakan variabel independen media sosial dan electronic word of mouth.

\section{DAFTAR PUSTAKA}

APJII. (2017). Infografis. Penetrasi \& Perilaku Pengguna Internet Indonesia, PP. 7-32.

Dailysocial. (2018). Local App Preference. Indonesia: Dailysocial.id.

Georgios Tsimonis, S. D. (2014). Brand strategies in social media. emeraldinsight, 1-2.

Hanaysha, J. R. (2018). An examination of the factors affecting consumer's purchase decision in the Malaysian retail market. PSU Research Review, 3-17.

Handi Handi, T. H. (2018). The Effect of EWOM and Perceived Value on the
Purchase Decision of Foods by Using the Go-Food Application as Mediated by Trust QUALITY

PROSPERITY/KVALITA

INNOVATION

PROSPERITA, 1-11.

Ismail, A. R. (2017). The influence of perceived social media marketing activities on brand loyalty: The mediation effect of brand and value consciousness. emeraldinsight, 1-5.

Jay M. Bernhardt, D. M. (2012). "Social marketing at the right place. Journal of Social Marketing, 3-5.

Keles Dikna Maria, P. K. (2016). The Effect Of Electronic Word Of Mouth On Consumer Buying Decision In Lazada. $E M B A, 2-8$.

Margaret McCann, A. B. (2015). "Use and measurement of social media for SMEs". emeraldinsight, 1-3.

Milad Farzin, M. F. (2018). "eWOM through social networking sites and impact on purchase intention and brand image in Iran. Journal of Advances in Management Research, 3-5.

Morse, K. (2016, Maret 07). What Is Social Media Engagement and What Does It Mean? Retrieved Oktober 21, 2018, from https://www.internetmarketinginc.com/blog /social-media-engagement-mean/

Oleksandra Pasternak, C. V.-T. (2017). Selfpresentation, privacy and electronic wordof-mouth in social media. Journal of Product \& Brand Management, 3-4.

Rawin Vongurai, D. E. (2018). Social Media Usage, Electronic Word of Mouth and Trust Influence Purchase-Decision Involvement in Using Traveling Service. Asia Pacific Journal of Multidisciplinary Research, 1-5.

Shantanu Prasad, I. C. (2017). Social media usage, electronic word of mouth and purchase-decision involvement. AsiaPacific Journal of Business Administration, 3-12.

Statista. (2018). Jumlah aplikasi yang tersedia di Google Play Store dari Desember 2009 hingga September 2018. Retrieved Oktober 20, 2018, from https://www.statista.com/statistics/266210/ number-of-available-applications-in-thegoogle-play-store/

Thorsten Hennig-Thurau, K. P. (2004). Electronic Word-Of-Mouth Via ConsumerOpinion Platforms: What Motivates 
Consumers To Articulate Themselves On The Internet ? 2-4.

Wearesocial. (2018, Januari 29). Digital in 2018 in Southeast Asia Part 2 - SouthEast. pp. 34-68. 
Rusli \& Mulyandi / Pengaruh Penggunaan Media Sosial, Electronic Word of Mouth ... 